\title{
THE KEY ASPECTS OF THE BUILDING AND APPLICATION OF TIME EQUATIONS IN COST CALCULATION
}

\author{
Mirjana Todorovic* \\ Faculty of Economics, University of Kragujevac, Kragujevac, Serbia
}

In addition to the capacity cost rate, the key parameter of Time-Driven Activity Based Costing - the TDABC is the time required for the realization of each business activity. In accordance with the TDABC methodology, the above-mentioned time is calculated by using time equations. Therefore, the total time required for the realization of a certain business activity is obtained by adding a normal (standard) time to the additional time required for performing modified forms of one and the same activity. The aim of this paper is to analyze the role and importance as well as various aspects of the building of time equations from the perspective of the organizational and methodological preparation for the realization and functioning of the TDABC. The research results show that the application of time equations leads to the increased accuracy of the calculation of costs and a product cost, reduces the complexity of the organizational and methodological preparation for the implementation and functioning of the TDABC system, i.e. enables the realization of a more effective and efficient costs calculation.

Keywords: calculation of costs, Time-Driven Activity Based Costing, capacity cost rate, time equations, time drivers

JEL Classification: M41, M49

\section{INTRODUCTION}

Time-Driven Activity Based Costing - the TDABC is thought to have originated from Activity Based Costing - the $\mathrm{ABC}$ in the early 1990s. It was the result of collaboration between S. Anderson and R. Kaplan. The TDABC was promoted as a system of exceptional information performances enabling gaining a full

\footnotetext{
* Correspondence to: M. Todorovic, Faculty of Economics, University of Kragujevac, Dj. Pucara 3, 34000 Kragujevac, Serbia; e-mail: mtodorovic@kg.ac.rs
}

insight into historical and future performances, efficient and effective short-term and long-term decision making and the evaluation of effectiveness in resource, activities and the management of a company's business processes (Everaert \& Bruggeman, 2007; Everaert, Cleuren \& Hoozee, 2012; Kaplan \& Anderson, 2007a; Kaplan \& Anderson, 2007b).

The TDABC methodology only requires the two sets of estimates: the capacity cost rate (the cost rate) and the time required for the realization of certain business tasks, activities or processes (Gilbert, 2007; 
Everaert, Bruggeman, Sarens, Anderson \& Levant, 2008; Everaert, Bruggeman \& De Creus, 2008; Kaplan \& Anderson, 2007a; Kaplan \& Anderson, 2007b; Malinić i Todorović, 2011; Todorović, 2013a). The capacity cost rate per unit of time is determined by dividing the total cost by a practical capacity. Total costs are the costs of specific pull resources, i.e. the costs of all resources required to perform a specific business activity. Therefore, the starting point in the TDABC is the costs in their total, collective (aggregated) amount (Antić, 2012; Antić i Georgijevski, 2010; Kaplan \& Anderson, 2007a; Szuhta, 2010).

The total available practical capacity is expressed in the time of all the resources engaged, e.g. employees who effectively work on the realization of a specific business activity. The TDABC identifies the quantity of the resources that actually perform specific business activities. The traditional ABC (Janjić i Todorović, 2012) is based on the assumption that all supplied resources of an enterprise are actually spent, thereby unjustifiably allocating costs of the unused capacity to cost objects. The TDABC represents a new generation of the cost accounting system based on the assumption that not all supplied resources (the capacity of an enterprise) are actually used resources. It seeks to identify and determine the volume of the costs of unused resources. Making a distinction between the costs of used and unused resources aims to correctly allocate costs to cost objects, i.e. to allocate the costs of resources to cost objects only when such resources are actually consumed (Antić i Georgijevski, 2010; Buchheit, 2003; Szuhta, 2010). The TDABC is characterized by a specific treatment of production costs, where only costs actually spent in activities of creating output are considered as production costs, which causes that all costs of an unused capacity are treated as costs of the period (Tse \& Gong, 2009).

In order to adequately allocate costs of resources to cost objects, based on the capacity cost rate, and to determine a product cost, it is necessary to determine the time required for the realization of specific business activities. The time variable is the basic cost driver and the key parameter of the TDABC. It is determined by time equations.
Accordingly, the segment of the organizational and methodological preparation for the TDABC application related to the creation and application of time equations for the purposes of determining the time required for the realization of business activities is the subject of research in this paper. Time equations are simple linear equations representing the quantitative basis of the TDABC. They allow an assessment of demand for resources (a capacity expressed in time) of each cost object.

Hence, the aim of the paper is to consider the role, importance, and different aspects of the building of time equations from the perspective of the organizational and methodological designing of the TDABC in the context of a more accurate cost allocation and determination of a product cost.

In accordance with the presented subject and aim of the research, the paper will test the following hypothesis: The application of time equations in the methodology of the TDABC enables the realization of a more effective and efficient calculation of costs. The effectiveness is related to an increased accuracy of cost calculation and the determination of a product cost, and the efficiency is related to the simplification of the calculation of cost procedures at an acceptable ratio of costs/profitability.

To test the hypothesis defined in the paper, the methodological procedures and techniques inherent to the social sciences will be applied, which means the qualitative methodology based on the study and a descriptive analysis of the defined subject of the research. Consulting the relevant literature, based on a theoretical analysis and examples from international practice, should provide the synthesis and drawing of general conclusions.

The paper consists of the four parts. The first part deals with the issues of the substantial determination of time equations and their importance from the perspective of the TDABC functioning. Since time equations are linear equations, the second part is devoted to various aspects of their design as well as to their being used for the purposes of the calculation of costs. The third part of the paper discusses multiple time drivers as the constitutive variables of time equations, whose 
application allows the building of an efficient and effective model of cost calculation in terms of frequent changes in operating conditions (which may induce changes in the cost calculation model) and complex business processes. The last, fourth part of the paper deals with the issues of the importance of the precision of time equations for cost calculation and the determination of a product cost, potential errors that appear in time equations and possible approaches to overcoming these errors.

\section{THE DETERMINATION OF TIME EQUATIONS}

The practice of measuring the required (spent) time of the engaged labor force and/or equipment in business processes, production in particular, is neither new nor unknown. Almost more than a century ago, the meaning and purpose of determining time included our understanding of the effects of the labor force and equipment and short-term quantitative improvements in accordance with the goals of mass production as well. The practice of measuring time is certainly important; from the perspective of the TDABC, however, the application the purpose of and an approach to measuring time for the realization of business activities (business processes), on the basis of the direct labor force, are neither sustainable nor acceptable for at least two reasons. Firstly, for the purposes of adequate cost management, it is not necessary that an absolutely accurate system (which would be based on more decimals) should be built; instead, it should be a system reflecting the actual situation. Secondly, the TDABC is applied for the purpose of detecting possibilities and making an initiative for long-term improvements rather than short-term goals and results. Hence, determining the time required for the realization of a certain business activity as the main TDABC parameter should be implemented in a substantially different manner and with a different meaning.

The calculation of the time required for the realization of a certain business activity in the TDABC depends on the usual or standard time required for its realization as well as an additional consumption of time in the case of new or different circumstances causing variations in the manner of the realization of such an activity. Thus, the total time required for the realization of a certain business activity is calculated by adding the usual (standard) time to the time required for the execution of the modified forms of the same activity caused by its variations. The complexity of determining the usual time as well as variations in the duration of some business activity caused by the influence of many factors can, in terms of the TDABC application, be overcome using time equations.

The quantitative i.e. mathematical basis of the TDABC consists of time equations. Time equations are linear equations allowing the determination of the time spent for the realization of a certain business activity. When applying time equations, the time required for the realization of a certain business activity is expressed as a function of different time drivers. In other words, the duration of a certain business activity depends on the specific characteristics of the activity itself, the conditions, and the manner of its carrying out, i.e. the above-mentioned time drivers. Time drivers are variables determining the time needed for an activity to be conducted. They represent the key constitutive variables of time equations and can take the form of (Todorović, 2013b):

- continuous variables (the weight of a pallet or a distance in kilometers),

- discrete variables (the number of orders, the number of credit cheques), or

- indicator variables (the type of customer: old vs. new; the type of order: regular vs. urgent).

Due to time equations and time drivers (as well as duration drivers, as opposed to the traditional $\mathrm{ABC}$ system predominantly based on transaction cost drivers), the TDABC makes an important step forward compared to the traditional $\mathrm{ABC}$. By applying time equations, the TDABC relatively easily incorporates variations in the time required for the realization of various types of business activities, on the one hand, or rejects a simplistic assumption that the realization of certain business activities always requires the same amount of time (Malinić i Todorović, 2011), on the other. The realization time for a certain business activity will not be the same, e.g. in the case of an order being processed for an old or a new buyer, or in the case 
of receiving either a regular (ordinary) or an urgent order. In this case, the type of customer or the type of order is a time driver determining the duration of an activity. The different time required for the realization of a certain business activity (time is the cost driver i.e. value determining the amount of a cost) will determine a corresponding amount of costs to be allocated to appropriate cost objects and an amount of a product cost. Organizational and methodological solutions designed in this way directly affect an increase in the reporting performances of the TDABC, or the overall information strength of cost accounting and the entire accounting information system (Todorović, 2008).

\section{BUILDING TIME EQUATIONS AND COST CALCULATION}

The building of time equations requires the identification of business activities and the determination of the drivers causing variations in the consumption of time for each business activity. It is, then, necessary to assess the required usual (standard) time for the realization of a business activity and the time required for the realization of modified forms of the same activity caused by the effect of time drivers, too. Based on the aforementioned data, a time equation is created. In general, the time required to perform a particular business activity can be expressed as a function of various characteristics, i.e. the so-called time driver. Hence, the time required to perform event $K$ of activity $J$, with $P$ possible numbers of time drivers $X$, generates the following time equation (Everaert \& Bruggeman, 2007, 17):

$t_{j, k}=\beta_{0}+\beta_{1} \times X_{1}+\beta_{2} \times X_{2}+\beta_{3} \times X_{3}+\ldots \ldots . .+\beta_{p} \times X_{p}$, where

$t_{j, k}$ - the time required to perform event $K$ of activity $J$,

$\beta_{0}$ - the constant amount of time for activity J, independent of the characteristics of the event,

$\beta_{1}$ - time consumption for one unit of time driver $1\left(\beta_{0^{\prime}}\right.$ $\beta_{1} \ldots \beta_{p}$ are constants in time consumption for different time drivers)

$X_{1}$ - time driver $1, X_{2}$ - time driver $2, X_{p}$ - time driver $p$, $p$ - the number of time drivers determining the time needed to perform activity .

This procedure can be presented in a hypothetical example of order processing at a sales department (Kaplan \& Anderson, 2007a, 29). The business activity of "order processing" includes: entering the order, entering every order line, setting up a new account (if it is a new buyer), the processing of urgent orders (checking the availability of the required items and the determination of the price) and the order confirmation. The starting assumptions of the analysis are as follows:

- the average time required for the realization of each of the business activities carried out at the sales department is determined, and

- all employees working in sales use the standard software, and the time required for each activity can easily be determined.

The processing of an order depends on three time drivers: $X_{1}$ - the number of order lines, as the discrete time driver, $X_{2}$ - the type of customer (a new vs. the existing one), as the indicator time driver, and $X_{3}$ - the type of order (ordinary versus urgent), as the indicator time driver. The indicator variable takes value 1 in the case of a new customer (or an urgent order) and 0 for an existing customer (or an ordinary order). The analysis of the time required for the realization of such activities indicates the following: entering information about the received order takes two minutes and entering information about each order line takes two minutes. Setting up a new account takes six minutes (if it is a new customer). Upon receiving an emergency order, it is necessary to check the availability of the requested items, which takes seven minutes, and determine the cost, which takes three minutes. The total increase in the time of "order processing", in the case of receiving an urgent order, is 10 minutes (due to the simplification of the analysis, the activity of receiving an urgent order will be considered as the whole, i.e. the aggregate amount of the time required will be used). The last activity relates to the development and validation of a delivery order, which takes one minute (this time is independent of the time driver in the case of "order processing", and will be abstracted for the purpose of the analysis). 
After identifying the average time needed for the realization of all business activities at the sales department in the case of "order processing" as well as the additional time spent due to the drivers (factors) of variation in time consumption, it is possible to create a time equation. In the case of the sales department, the sales time ( $t$ ) can be determined as follows (Todorović, 2013a, 162):

$t=$ entering order + entering every order line + setting up a new account + processing of urgent orders.

Mathematically expressed by the general time equation, it is as follows:

$t=\beta_{0}+\beta_{1} \times X_{1}+\beta_{2} \times X_{2}+\beta_{3} \times X_{3}$.

In this case, the time equation for calculating the time of the processing of one single order $(t)$ has the following form:

$t=2+2 \times X_{1}+6 \times X_{2}+10 \times X_{3}$

If one were to assume that an urgent 10-item order was received by the company from a new customer, the time equation would result in the following time of the processing of a single order:

$t=2+2 \times 10+6 \times 1+10 \times 1=38$ minutes.

It is apparent that the time equations allow an efficient inclusion and involvement of complex business operations in cost calculation. However, the key requirement for the successful functioning of cost accounting, based on the application of the TDABC and the time equations, is an adequate information (software) support. The aggressive emergence of information technologies in the field of accounting, particularly in management accounting, has resulted in changes not only in its conceptual and organizational basis, but primarily in the development and implementation of new methodological approaches to the realization of accounting procedures. An important step in this direction has been made by designing the software that not only supports the realization of activity-based costing (for example), but the software creates itself on the basis of it. The performance of the contemporary cost accounting systems without an adequate software support is almost inconceivable. The ERP-type software shows an outstanding performance in terms of the availability and accessibility of inputs required for the creation of time equations and the functioning of the TDABC. Therefore, calculating the time required for the realization of various business activities is far simpler in terms of the application of the ERP systems.

After having designed time equations and determined the duration of business activities, the calculation of costs follows by multiplying the time required for the realization of a certain business activity by the cost capacity rate. Since the time required for the realization is determined according to each specific case, in accordance with its characteristics, the cost $(T)$ of individual event $K$, of activity $J$ shall be determined according to the following formula:

$T=t_{j, k} \times c_{\min }$, where

$c_{\min }$ - is the cost per time unit (minute),

$t_{j, k}$ - is the time consumed by event $K$ of activity $J$.

The total cost for a cost object is estimated by summing up all the activity costs:

Total costs $=\sum_{i=1}^{n} \sum_{j=1}^{m} \sum_{k=1}^{l} t_{j, k} \times c_{\min }$, where:

$n$ - is the number of resource pools,

$m$ - is the number of activities, and

$l$ - is the number of times activity $\mathrm{J}$ is performed.

Companies that have already mapped their processes, in the processes of the organizational and methodological designing of the TDABC, can directly build their time equations. Those without process maps can start at a simpler level by estimating the minimum time needed to perform the process, which will be marked with $\beta_{0}$. Then, in accordance with the effect of activity variations (caused by time drivers), time will be added (from $\beta_{1}$ to $\beta_{\mathrm{p}}$ ) to the time equation. If we observe the storage department or the product 
packaging department, for example, the packaging of a standard item in the package can be assumed to take one minute. Longer transport necessitates a specific package, which takes additional seven minutes, and if the product is transported by plane, additional two minutes are needed. Instead of individually defining the duration of each activity for each possible combination of product characteristics, the approach based on time estimates the demand of the department for resources using the time equation, according to which, on the basis of the assumptions, the time of packaging is $1+7+2$. For low-cost or low-variability processes, a single time driver can be sufficient (it is not necessary to build time equations). Building a time equation is mandatory for high-cost processes and for processes with a significant variability.

With regard to the design and realization of time equations, it is necessary to (Kaplan \& Anderson, 2007a, 35-36):

- start the TDABC with high-cost and timeconsuming processes;

- precisely define the scope of the processes, what initiates them and when;

- correctly determine the key time drivers for each activity, or the most significant factor which influences time consumption (the capacity);

- use readily available cost drivers;

- strive to simplicity, and

- engage employees to help build and validate the cost model.

In addition to the project team, who are responsible for designing the model of time equations, the role of all employees directly involved in the realization of activities and business processes should be emphasized. Employees are the most important source of information concerning the scope and complexity of activities or the time required for their realization. The building of time equations requires that workers be interviewed. However, the subject of such an interview is not information on the percentage allocation of time to activities, as it is the case in the traditional $\mathrm{ABC}$, but rather on the actual consumption of time. Data on the time spent per activity may in some cases be directly estimated or identified, i.e. they may be obtained from the company's information system, with no need to interview workers.

\section{THE APPLICATION OF MULTIPLE TIME DRIVERS IN TIME EQUATIONS}

One of the first studies on the practical application of the TDABC and time equations was carried out in Belgium, in the case of wholesale trade. One of the primary goals of the research was to analyze the ability of the TDABC to cover complex business activities in logistics, and therefore result in accurate cost calculation. The results showed that complex business activities in logistics cannot be included in the cost model without using time equations with multiple time drivers (Everaert et al, 2008, 187). Time equations designed on the basis of a number of different time drivers are much more realistic since the duration of an activity not only depends on many factors but also on their mutual relation. The authors of the study discussed the impact of the application of multiple time drivers and their mutual relationship on the duration of activities through various hypothetical examples (Everaert \& Bruggeman, 2007, 19).

For the purposes of illustrating the impact of the interdependence of time drivers on the time of the realization of a certain business activity, two cases will be analyzed. The first relates to the existence of a twoway interaction in time drivers and the second one is related to the existence of a three-way interaction in time drivers. The basis of the analysis that follows will include the already discussed example of "order processing" at a company's sales department. Please be reminded that the processing of an order depends on the three time drivers: $X_{1}$ - the number of order lines, as the discrete time driver, $X_{2}$ - the type of customer (new vs. existing), as the indicator time driver, and $X_{3}$ the type of order (ordinary vs. urgent), as the indicator time driver. The indicator variable takes value 1 in the case of a new customer (or an urgent order) and 0 for an existing customer (or an ordinary order). In the case of the existence of a two-way interaction in time drivers, taking into account the earlier assumptions, it 
is further assumed that a complex order from customer $X$ arrives in the sales department. Complexity refers to the existence of detailed technical data in the order, which causes an increase in the time required for the entry of this order items from two to ten minutes. In this case, the time equation must include a new time driver. A new time driver is marked with $X_{4}$ and determines the processing time per item of a complex order. The driver has an indicator character, which means that it will have the value of 1 if the customer is $X$ or the value of 0 , in the case of any other customer. Based on the earlier assumptions, the general time equation can be mathematically expressed as follows:

$t=\beta_{0}+\beta_{1} \times X_{1}+\left[\beta_{4} \times X_{1} \times X_{4}\right]+\beta_{2} \times X_{2}+\beta_{3} \times X_{3}$

In this case, the time equation for calculating the time processing of one order $(t)$ has the following form:

$t=2+2 \times X_{1}+\left[8 \times X_{1} \times X_{4}\right]+6 \times X_{2}+10 \times X_{3}$.

If a complex 10-item order of customer $\mathrm{X}$ is assumed to have been received by the company, the time equation would result in the following time of the processing of a single order:

$t=2+2 \times 10+8 \times 10 \times 1+6 \times 0+10 \times 0=102$ minutes.

In the case of the existence of a three-way interaction in time drivers, the assumption of Case Number 2 will be retained, that is the assumption of the appearance of a technically complex order. However, an additional assumption will be made, according to which it will take eight minutes to process, if such an order is processed by an administrative department worker, while if it is processed by a person with appropriate technical knowledge, such processing will take three minutes. For these reasons, it is necessary that a new driver $X_{5^{\prime}}$ which will indicate the type of order depending on the person processing it, of an indicator character, should be introduced. This means that it will have the value of 1 , if the order is processed by an administrative worker, or the value of 0 , if it is processed by technical staff. Based on the abovementioned, the general time equation for determining the processing time of one single order $(t)$ is as follows: $t=\beta_{0}+\beta_{1} \times X_{1}+\beta_{4} \times X_{1} \times X_{4}+\left[\beta_{5} \times X_{1} \times X_{4} \times X_{5}\right]+\beta_{2} \times X_{2}+$ $\beta_{3} \times X_{3}$

or, in this specific case, the time equation for calculating the time of the processing of one order $(t)$ has the following form:

$\mathrm{t}=2+2 \times X_{1}+3 \times X_{1} \times X_{4}+\left[5 \times X_{1} \times X_{4} \times X_{5}\right]+6 \times X_{2}+$ $10 \times X_{3}$.

The time equation assuming that the received order is from customer $X$, contains three items and is processed by an employee with required technical competencies results in the following time of the processing of one single order:

$t=2+2 \times 3+3$ ff $\times 3 \times 1+5 \times 3 \times 1 \times 0+6 \times 0+10 \times 0=$ 17 minutes.

The example clearly indicates a three-way interaction in the number of items in the order (the discrete factor), the type of customer and the type of order depending on the person processing it (both indicator factors).

The application of multiple time drivers, together with their inclusion in time equations, provides companies with the simplified acceptance of their own complexity without a need to increase the complexity of costing models. Instead of defining new activities and subactivities, new time equations are introduced (or the existing ones are extended) and the whole process is simplified. This is another very important advantage of using time equations alongside their contribution to an increase in the accuracy in cost calculation. To encompass the increasing complexity of the operations or variations of a business activity, the traditional $A B C$ requires the decomposition of business operations into specific activities and sub-activities, i.e. the creation of the Register of Activities. The costing model, which is the basis of the TDABC, is getting linearly complicated with the increasing complexity of corporate operations, rather than exponentially as a calculation model being the basis of the traditional $\mathrm{ABC}$. There are cases in which, by the implementation of the TDABC, over 900 identified business activities in the Register of Activities are replaced with only 100 time equations. Due to multiple time drivers, the TDABC model is based on a smaller number of time 
equations than the number of activities that would be necessary in the cost model based on the traditional $\mathrm{ABC}$, whereas simultaneously, it allows a much greater variety and complexity of business operations (Kaplan \& Anderson, 2007b, 17).

\section{POTENTIAL ERRORS IN TIME EQUATIONS}

In the process of creating time equations, there are two types of errors that may arise: identification errors and errors in estimates. The emergence of an identification error is caused by a high level of detail in data for the creation of time equations and a possible omission of certain time drivers. The consequence of their omission is an insufficiently precisely determined time for the realization of business activities (Hoozee, Vermeire \& Bruggeman, 2012, 442).

Errors in estimates or measurement errors are numerous and occur for several reasons. In this regard, it should be keep in mind that inputs for the formation of time equations are either the existing or ex-post data, obtained by directly engaged operational staff, a company's management, and/or from a company's existing information system. The first cause of measurement error is associated with incorrect estimates of time by employees, concerning the parameters of time equations. In addition to accidental errors, incorrect time estimates can deliberately be made, with a bias. Incorrect estimates can arise as the consequence of the fact that the staff are required to estimate the duration in percentages rather than in minutes (Cardinaels \& Labro, 2008, 736). Some psychological studies show that systematic errors in estimates of time, either an underestimation or an overestimation, are related to the length of time interval which time is estimated for. The results of the studies have showed that time is often overestimated for shorter time intervals (Fortin \& Rousseau, 1998, 271).

As a frequent cause of misestimates of time, there are inaccurate or unreliable data contained in a company's information system, from which they are withdrawn for the purposes of creating time equations and calculating costs. The imprecision and inaccuracy of inputs results through inadequately formulated time equations in low-quality outputs, i.e. the incorrect time of the realization of business activities (business processes or transactions) (Labro \& Vanhoucke, 2007, $940)$ and has a negative effect on the calculated costs.

The last group of causes of errors in estimates of time are associated with the organizational and methodological aspects of the TDABC implementation and are usually a consequence of an inadequate level of the aggregation of business activities defined in the costing system or a high level of correlation between tasks within activities (business processes). This is exactly one of the most emphasized potential disadvantages of the TDABC. The identification and selection of business activities aims to create a clear and reliable basis of the bookkeeping, encompassing and calculation of costs. It is a complex process directly determined by the size and organizational structure of a company, the type of activity, the objectives of cost calculation and many other factors. The creating of adequate organizational and methodological solutions in this regard goes beyond the framework of the issue of time equations or touches the fundamental questions of the organization and functioning of the TDABC.

Errors in estimates and identification errors can be found in specific mutual relations. The consequence of increasing the level of detail through the expansion of time equations in order to reduce the identification of potential errors in the determination of the time required for the realization of certain business activities is a more accurate calculation (more accurate data and information) as well as higher costs of creating such information. Since inputs of time equations are subject to error estimation, it is uncertain whether making an increase in the level of detail would really contribute to the determination of the accurate time of the realization of activities, i.e. business processes. The existence of potential errors in estimates may cause the extension of time equations to result in an increase in error in determining the time of the realization of an activity rather than in an increase in the accuracy of a calculation. Hence, when designing time equations, one should strive to establish an optimal relation, 
i.e. a balance between the errors in estimation and identification errors.

Bearing in mind that the possession of information on the magnitude of potential errors is important for designing a cost system and users of its information, numerous studies have attempted to analyze this problem in detail. The applied approaches differed from one another, ranging from simulation (Labro \& Vanhoucke, 2007, 941) to statistical and mathematical ones. Statistical and mathematical models are very successful for determining the impact of expanding time equations (by adding parameters, i.e. time drivers) on the accuracy of the determined time for the realization of activities. These models observe the relationship between the magnitude of the estimation error and the identification error and their impact on the accuracy of the determined time for the realization of an activity. An analysis based on the application of statistical and mathematical models should result in minimizing potential errors when designing and applying time equations. Some recommendations involve the expansion of time equations with time drivers, according to priority (based on statistical parameters: the mean and the variance) and merging a variety of drivers into a single one, if there is a significant correlation between them, in order to minimize the identification error. The models insist on the application of certain practical tools and general procedures when creating time equations so as to eliminate or minimize potential errors.

\section{CONCLUSION}

The fact that the TDABC is founded on time equations and time drivers (and therefore duration drivers) provides it with significant methodological advantages and a high reporting performance comparing to the previous solutions of activity-based costing. The most important are the following ones:

- The TDABC provides a greater accuracy of cost calculation, i.e. determined product costs. The accuracy of the TDABC is based on an adequate allocation of costs to cost objects in accordance with the actual consumption of resources. Increasing the accuracy and flexibility of cost calculation does not increase the complexity of calculation, due to a possibility of designing time equations with multiple time drivers;

- for the purposes of the system update, the application of the traditional $\mathrm{ABC}$ requires that almost at the end of each accounting period interviews with employees should be done in order to re-estimate the time required for the realization of business activities. A need to reestimate the time required can be due to the introduction of new products, new processes, the emergence of new customers, and the like. In terms of the TDABC application, time equations constantly change with as there is an increase in the number and complexity of activities, in terms of introducing new products, processes, customers or distribution channels, thus enabling a more efficient system update. Furthermore, any omission of some important variations of a process, sub-process, or activity in terms of applying time equations is simply overcome by having them expanded;

- time equations have a special use value from the perspective of a company's management. Since they include the basic factors provoking demand for the process capacity, including changes in the efficiency of the process, production volume and mix, and the like, time equations are very suitable for the simulation of a future, for implementing a what if analysis, for improving the budgeting process and for an efficient analysis of a company's capacity;

- the process of designing time equations often results in identifying the process, activity, or certain phases of an activity that are inefficient and cause unnecessary spending, i.e. waste of resources. This ensures a kind of initial impulse to propose an initiative of improving business processes, i.e. time equations provide the basis for the continuous operational improvements of business processes (Everaert et al, 2012, 41; Hoozee \& Bruggeman, 2010, 185).

- during the process of creating time equations, identification errors or estimation errors might 
emerge. Numerous empirical studies have dealt with the analysis pf and manners how to eliminate these potential errors (Hoozee et al, 2012; Cardinaels \& Labro, 2008; Fortin \& Rousseau, 1998; Labro \& Vanhoucke, 2007). The findings suggest the application of specific practical tools and techniques (simulation, statistical and mathematical) and general procedures for creating time equations in order to eliminate or minimize errors.

The key attributes of the methodology, i.e. of the costing model, based on time equations are as follows: its simplicity and flexibility, convenience for customization and expansion, high precision and accuracy, and simplified maintenance and updating. In other words, due to time equations, the TDABC enables an effective and efficient calculation of costs and the determination of a product cost. Challenges of time and changes will provide us with the answer to the question of the long-term viability and applicability of this modern cost accounting system. However, the analysis carried out and the conclusions drawn confirm the hypothesis stated at the beginning of the work.

The conducted analysis and the presented conclusions contribute to the understanding of the essence, methodology and reporting performance of the TDABC system and have a significant practical value from the perspective of the application and dispersion of this system in Serbian companies. The shown examples concerning the process of building time equations provide a foundation for the improvement of the TDABC systems in companies that have already been applying it. Also, they help overcome problems and fulfil the assumptions of the organizational and methodological preparation for the implementation and functioning of this system for potential users.

The overall research efforts in this paper, predominantly oriented towards the organizational and methodological aspects of the TDABC, have opened numerous questions and dilemmas. The analysis of these issues will attract the attention of researchers in the future, primarily concerning the building of the accounting model based on the TDABC in companies' practices. The broader theoretical and methodological foundation and the diffusion of the
TDABC in practice will enable the realization of other statistical and mathematical research methodologies. The analysis of numerous studies in the world practice concerning the TDABC application can serve as a useful basis for future studies.

\section{REFERENCES}

Antić, Lj. (2012). Koncepti obračuna i upravljanja troškovima u poslovnom okruženju. U R. Stojanović (Ur.), Ekonomskofinansijska kriza i računovodstveni sistem (str. 144-165). Beograd: SRRS.

Antić, Lj. i Georgijevski, M. (2010). Obračun troškova po aktivnostima zasnovan na vremenu. Ekonomske teme, 48(4), 499-513

Buchheit, S. (2003). Reporting the Cost of Capacity. Accounting Organizations and Society, 28(6), 549-565. doi: 10.1016/S03613682(02)00014-4.

Cardinaels, E., \& Labro, E. (2008). On the determinants of measurement error in time-driven costing. The Accounting Review, 83(3), 735-756.

Everaert, P., \& Bruggeman, W. (2007). Time-Driven ActivityBased Costing: Exploring the Underlying model. Cost Management, 21(2), 16-20.

Everaert, P., Bruggeman, W., \& De Creus, G. (2008). Sanac Inc.: from $\mathrm{ABC}$ to Time driven $\mathrm{ABC}$ (TDABC) - an instructional case. Journal of Accounting Education, 26(3), 118-154. doi: 10.1016/j.jaccedu.2008.03.001.

Everaert, P., Bruggeman, W., Sarens, G., Anderson, S., \& Levant, Y. (2008). Cost modeling in logistics using timedriven ABC: Experiences from a wholesaler. International Journal of Physical Distribution \& Logistics Management, 38(3), 172-191. doi: 10.1108/09600030810866977.

Everaert, P., Cleuren, G., \& Hoozee, S. (2012). Using TimeDriven $\mathrm{ABC}$ to identify operational improvements: a case study in a university restaurant. Cost Management, 26(2), 4148 .

Fortin, C., \& Rousseau, R. (1998). Interference from short-term memory processing on encoding and reproducing brief durations. Psychological Research, 61(4), 269-276. doi: 10.1007/ s004260050031.

Gilbert, S. (2007). Adding Time to ABC. Working Knowledge, Harvard Business School, Retrieved 25.06.2014. from http:/ www.exed.hbs.edu/assets/documents/activity-basedcosting.pdf. 
Hoozee, S., \& Bruggeman, W. (2010). Identifying operational improvements during the design process of time-driven $\mathrm{ABC}$ system: the role of collective worker participation and leadership style. Management Accounting Research, 21(3), 185198. doi: 10.1016/j.mar.2010.01.003.

Hoozee, S. M., Vermeire, L., \& Bruggeman, W. (2012). The impact of refinement on the accuracy of time-driven ABC. Abacus, 48(4), 439-472. doi: 10.1111/j.1467-6281.2012.00366.x.

Janjić, V. i Todorović, M. (2012). Izveštajni dometi obračuna troškova po aktivnostima u poslovnom odlučivanju. Teme, 36(1), 237-252.

Kaplan, R., \& Anderson, S. (2007a). Time - Driven Activity Based Costing: A Simpler and more Powerful path to higher profits. Boston, USA: Harvard Business School Publishing Corporation.

Kaplan, R., \& Anderson, S. (2007b). The innovation of Time Driven Activity-Based Costing. Cost Management, 21(2), 5-15.

Labro, E., \& Vanhoucke, M. (2007). A simulation analysis of interactions among errors in costing systems. The Accounting Review, 82(4), 939-962.
Malinić, S. i Todorović, M. (2011). Konceptualne osnove obračuna i upravljanja troškovima po aktivnostima baziranom na vremenu. Ekonomika preduzeća, 59(3-4), 206213.

Szuhta, A. (2010). Time-Driven Activity-Based Costing in Service Industries. Social Science, 67(1), 49-60.

Todorović, M. (2008). Koncipiranje analitičkog kontnog plana računovodstva troškova u skladu sa MRS/MSFI i Zakonom o računovodstvu i reviziji. Ekonomski horizonti, 10(1-2), 131158.

Todorović, M. (2013a). Obračun troškova po aktionostima baziran na vremenu -instrument integrisanog upravljanja lean poslovnim procesima. Neobjavljena doktorska disertacija, Ekonomski fakultet Univerziteta u Kragujevcu, Kragujevac, Srbija.

Todorović, M. (2013b). Izbor uzročnika troškova u funkciji izgradnje optimalnog sistema obračuna troškova po aktivnostima. Računovodstvo, 57(7-8), 61-71.

Tse, M., \& Gong, M. (2009). Recognition of Idle Resources in TDABC and RCA. Jamar, 7(2), 41-54.

\section{Received on $14^{\text {th }}$ November 2014, after revision, accepted for publication on $15^{\text {th }}$ December 2014. \\ Published online on $22^{\text {nd }}$ December 2014}

Mirjana Todorovic is an Assistant Professor at the Faculty of Economics - the University of Kragujevac, Kragujevac, Serbia, where she obtained her PhD degree in the scientific field of Accounting, Auditing and Business finance. The key areas of her interest are contemporary cost accounting and cost management systems as well as different aspects of the accounting information systems. 


\title{
KLJUČNI ASPEKTI KREIRANJA I PRIMENE JEDNAČINA VREMENA U OBRAČUNU TROŠKOVA
}

\author{
Mirjana Todorović* \\ Ekonomski fakultet Univerziteta u Kragujevcu
}

Pored troškova resursa po jedinici vremena, ključni parametar obračuna troškova po aktivnostima zasnovanog na vremenu (Time-Driven Activity Based Costing - TDABC) je vreme potrebno za realizaciju svake poslovne aktivnosti. Pomenuto vreme se, u skladu sa metodologijom TDABC sistema, utvrđuje pomoću jednačina vremena. Prema jednačinama vremena, vreme potrebno za realizaciju određene poslovne aktivnosti se dobija kao zbir uobičajenog (standardnog) vremena potrebnog za njeno izvršenje i dodatnog vremena potrebnog za izvršenje izmenjenih oblika aktivnosti. Cilj postavljen radom jeste sagledavanje uloge, značaja, i različitih aspekata kreiranja jednačina vremena iz perspektive organizacionometodoloških priprema za implementaciju i funkcionisanje TDABC sistema. Rezultati istraživanja ukazuju na to da primena jednačina vremena doprinosi preciznijem obračunu troškova i cene koštanja, smanjenju kompleksnosti u domenu organizaciono-metodoloških priprema za implementaciju i kasnije funkcionisanje TDABC sistema, odnosno, efektivnijem i efikasnijem obračunu troškova.

Ključne reči: obračun troškova, obračun troškova po aktivnostima zasnovan na vremenu, troškovi resursa po jedinici vremena, jednačine vremena, faktori trajanja aktivnosti

JEL Classification: M41, M49

\section{UVOD}

Obračun troškova po aktivnostima zasnovan na vremenu (Time-Driven Activity Based Costing - TDABC) nastao je na osnovama tradicionalnog obračuna troškova po aktivnostima (Activity Based Costing - $\mathrm{ABC}$ ), početkom devedesetih godina XX veka. Rezultat je zajedničkog rada S. Anderson-a i R. Kaplan-a. Promovisan je kao sistem izuzetnih izveštajnih performansi, koji omogućava potpuni

\footnotetext{
* Korespondencija: M. Todorović, Ekonomski fakultet Univerziteta u Kragujevcu, Đ. Pucara 3, 34000 Kragujevac, Srbija; e-mail:mtodorovic@kg.ac.rs
}

uvid $\mathrm{u}$ istorijske i buduće performanse, efikasno i efektivno, kratkoročno i dugoročno odlučivanje i ocenu efektivnosti upravljanja resursima, aktivnostima i poslovnim procesima preduzeća (Everaert \& Bruggeman, 2007; Everaert, Cleuren \& Hoozee, 2012; Kaplan \& Anderson, 2007a; Kaplan \& Anderson, 2007b).

Metodologija TDABC sistema je zasnovana na proceni dva parametra: troškova resursa po jedinici vremena i vremena potrebnog za realizaciju određenih zadataka, poslovnih aktivnosti ili procesa (Gilbert, 2007; Everaert, Bruggeman, Sarens, Anderson \& Levant, 2008; Everaert, Bruggeman \& De Creus, 2008; Kaplan \& 
Anderson, 2007a; Kaplan \& Anderson, 2007b; Malinić i Todorović, 2011; Todorović, 2013a). Troškovi resursa po jedinici vremena se utvrđuju kao količnik ukupnih troškova i praktičnog kapaciteta. Kategorija ukupnih troškova obuhvata ukupne troškove određene grupe resursa, odnosno, svih resursa potrebnih za realizaciju konkretnih poslovnih aktivnosti. Prema tome, ishodište obračuna troškova u TDABC sistemu jesu troškovi u ukupnom iznosu (Antić, 2012; Antić i Georgijevski, 2010; Kaplan \& Anderson, 2007b; Szuhta, 2010).

Ukupno raspoloživi praktični kapacitet se izražava $\mathrm{u}$ vremenu angažovanja svih resursa, na primer, zaposlenih radnika koji efektivno rade na realizaciji konkretnih poslovnih aktivnosti. Da bi procenio praktični kapacitet, TDABC identifikuje obim resursa koji su zaista angažovani i trošeni na obavljanju konkretnih poslovnih aktivnosti. Tradicionalni obračun troškova po aktivnostima (ABC) (Janjić i Todorović, 2012) polazi od pretpostavke da su svi angažovani resursi preduzeća stvarno i potrošeni. Posledično, troškovi neiskorišćenog kapaciteta se neopravdano dodeljuju nosiocima troškova. TDABC predstavlja novu generaciju sistema obračuna troškova u čijoj osnovi je pretpostavka da nisu svi angažovani resursi (kapacitet preduzeća) i stvarno iskorišćeni, odnosno, teži da identifikuje i utvrdi neiskorišćeni kapacitet preduzeća. Razgraničenje između troškova iskorišćenih i neiskorišćenih resursa ima za cilj pravilno dodeljivanje troškova nosiocima troškova, tj. alokaciju troškova resursa na nosioce troškova samo onda kada su resursi stvarno potrošeni (Antić i Georgijevski, 2010; Buchheit, 2003; Szuhta, 2010). Prema tome, TDABC $\mathrm{u}$ proizvodne troškove uključuje samo stvarno nastale troškove $\mathrm{u}$ aktivnostima kreiranja output-a, dok troškove neiskorišćenog kapaciteta tretira kao troškove perioda (Tse \& Gong, 2009).

Kako bi se na osnovu troškova resursa po jedinici vremena, troškovi resursa adekvatno alocirali na nosioce troškova i utvrdila cena koštanja, neophodno je utvrditi vreme potrebno za realizaciju konkretnih poslovnih aktivnosti. Varijabla vreme predstavlja osnovni uzročnik troškova i ključni parametar TDABC sistema. Ono se utvrđuje pomoću jednačina vremena.
Prema tome, predmet istraživanja $\mathrm{u}$ radu je segment organizaciono-metodoloških priprema za primenu TDABC sistema koji se odnosi na kreiranje i primenu jednačina vremena za svrhe utvrđivanja vremena realizacije poslovnih aktivnosti. Jednačine vremena su jednostavne linearne jednačine i predstavljaju kvantitativnu osnovu TDABC sistema. One omogućavaju procenu tražnje za resursima (kapacitetom iskazanim u vremenu) svakog nosioca troška.

Otuda, cilj postavljen radom je razmatranje uloge, značaja i različitih aspekata kreiranja jednačina vremena iz perspektive organizaciono-metodološkog koncipiranja TDABC sistema, a u kontekstu preciznije alokacije troškova i utvrđivanja cene koštanja.

Saglasno postavljenom predmetu i cilju istraživanja u radu će biće testirana sledeća hipoteza: Primena jednačina vremena $\mathrm{u}$ metodologiji TDABC sistema omogućava realizaciju efektivnijeg i efikasnijeg obračuna troškova. Pri tome, efektivnost se odnosi na povećanu preciznost obračuna troškova i utvrđivanja cene koštanja, a efikasnost na pojednostavljenje procedure obračuna troškova uz prihvatljiv odnos troškovi/profitabilnost.

Radi testiranja definisane hipoteze $u$ radu ce biti primenjeni metodološki postupci i tehnike svojstveni društvenim naukama, tj. kvalitativna metodologija bazirana na proučavanju i deskriptivnoj analizi definisanog predmeta istraživanja. Konsultovanje relevantne literature, zasnovane na teorijskim analizama i primerima iz svetske prakse, treba da omogući svojevrsnu sintezu i izvođenje opštih zaključaka.

Strukturu rada čine četiri dela. Prvi deo rada se bavi pitanjima određenja jednačina vremena i njihovim značajem iz perspektive funkcionisanja TDABC sistema. Budući da jednačine vremena predstavljaju linearne jednačine, drugi deo rada je posvećen različitim aspektima njihovog koncipiranja, ali i korišćenja za svrhe obračuna troškova. U trećem delu rada razmatraju se višestruki uzročnici potrošnje vremena - faktori trajanja aktivnosti, kao konstitutivne varijable jednačina vremena, čija primena omogućava izgradnju efikasnog i efektivnog modela obračuna 
troškova u često izmenljivim uslovima poslovanja (koje mogu izazivati promene u modelu obračuna troškova) i kompleksnih poslovnih procesa. Četvrti deo rada bavi se pitanjima značaja preciznosti jednačina vremena za obračun troškova i utvrđivanje cene koštanja, potencijalnim greškama koje se pojavljuju $\mathrm{u}$ jednačinama vremena i mogućim pristupima za prevazilaženje ovih grešaka.

\section{ODREĐENJE JEDNAČINA VREMENA}

Praksa merenja potrebnog (potrošenog) vremena angažovane radne snage $\mathrm{i} / \mathrm{ili}$ opreme $u$ poslovnim procesima, pre svega, proizvodnji, nije nova i nepoznata. Pre više od jednog veka, smisao i svrha utvrđivanja tog vremena bili su sagledavanje učinaka radne snage i opreme, ali i kratkoročna kvantitativna unapređenja $\mathrm{u}$ skladu sa ciljevima masovne proizvodnje. Postojanje prakse merenja vremena svakako da je od značaja, ali, iz perspektive primene TDABC sistema, svrha i pristup merenja vremena realizacije poslovnih aktivnosti na bazi direktnog ljudskog rada nisu održivi i prihvatljivi najmanje iz dva razloga. Prvo, za svrhe adekvatnog upravljanja troškovima nije potrebno izgraditi apsolutno precizan sistem (koji bi se bazirao na više decimala), već sistem koji će odražavati stvarno stanje. Drugo, smisao primene TDABC sistema je otkrivanje mogućnosti i pokretanje inicijativa za dugoročna unapređenja, a ne kratkoročni ciljevi i rezultati. Otuda, utvrđivanje vremena potrebnog za realizaciju određene poslovne aktivnosti, kao osnovnog parametra TDABC sistema, treba sprovoditi na suštinski drugačiji način i sa drugačijim smislom.

Izračunavanje vremena potrebnog za realizaciju određene poslovne aktivnosti u TDABC sistemu je uslovljeno potrebnim uobičajenim ili standardnim vremenom za njenu realizaciju, ali i dodatnom potrošnjom vremena $u$ slučajevima pojave novih, ili drugačijih, okolnosti koje izazivaju varijacije u načinu realizacije aktivnosti. Prema tome, ukupno vreme potrebno za realizaciju određene poslovne aktivnosti dobija se sabiranjem uobičajenog (standardnog) vremena sa vremenima potrebnim za izvršenje modifikovanih oblika iste aktivnosti uslovljenih njenim varijacijama. Kompleksnost utvrđivanja uobičajenog, ali i varijacija $u$ vremenu trajanja neke poslovne aktivnosti uslovljene dejstvom brojnih faktora, $\mathrm{u}$ uslovima primene TDABC sistema prevazilazi se upotrebom jednačina vremena.

Jednačine vremena predstavljaju kvantitativnu, tj. matematičku osnovu TDABC sistema. Reč je o linernim jednačinama, koje omogućavaju utvrđivanje vremena koje se potroši za realizaciju određene poslovne aktivnosti. Pomoću jednačina vremena, vreme potrebno za realizaciju određene poslovne aktivnosti izražava se kao funkcija više različitih uzročnika potrošnje vremena ili faktora trajanja aktivnosti. Odnosno, trajanje određene poslovne aktivnosti zavisi od specifičnih karakteristika same aktivnosti, uslova i načina njenog izvršenja, odnosno, od pomenutih faktora trajanja aktivnosti. Faktori trajanja aktivnosti su varijable koje određuju vreme potrebno za izvršenje određene poslovne aktivnosti, i predstavljaju ključne konstitutivne elemente jednačina vremena. Oni mogu biti (Todorović, 2013b):

- kontinuirani (na primer, težina palete ili razdaljina u kilometrima),

- diskretni (na primer, broj porudžbina i broj kreditnih provera) ili

- indikatorski (na primer, tip klijenta - stari ili novi; tip porudžbine - uobičajena ili hitna porudžbina i dr.).

Zahvaljujući jednačinama vremena i faktorima trajanja aktivnosti (ali i uzročnicima troškova zasnovanim na trajanju, za razliku od tradicionalnog $A B C$ sistema koji se dominantno bazira na transakcionim uzročnicima troškova), TDABC čini važan iskorak u odnosu na tradicionalni $\mathrm{ABC}$. TDABC sistem relativno jednostavno, pomoću jednačina vremena, inkorporira varijacije u potrebnom vremenu za realizaciju različitih tipova poslovnih aktivnosti, odnosno, odbacuje pojednostavljenu pretpostavku da realizacija određene poslovne aktivnosti uvek zahteva isto vreme (Malinić i Todorović, 2011). Vreme realizacije određene poslovne aktivnosti, neće biti isto, na primer, u slučaju da se obrađuje porudžbina starog ili novog kupca, ili u slučaju prispeća redovne ili hitne porudžbine. Tip kupca ili tip porudžbine u ovom slučaju predstavljaju 
faktor trajanja aktivnost, koji određuje vreme trajanja aktivnosti. Različito vreme potrebno za realizaciju određene poslovne aktivnosti (ovo vreme predstavlja uzročnik troška, odnosno, veličinu koja određuje visinu troška) će odrediti i pripadajući iznos troškova koji će biti alocirani na odgovarajuće nosioce troškova (u konačnom, veličinu cene koštanja). Na ovaj način koncipirana organizaciono-metodološka rešenja direktno utiču na povećanje izveštajnih performansi TDABC sistema, odnosno, na ukupnu informacionu snagu računovodstva troškova i celokupnog računovodstvenog informacionog sistema (Todorović, 2008).

\section{KREIRANJE JEDNAČINA VREMENA I OBRAČUN TROŠKOVA}

Izrada jednačina vremena zahteva identifikovanje poslovnih aktivnosti i utvrđivanje faktora koji izazivaju varijacije $\mathrm{u}$ potrošnji vremena za svaku poslovnu aktivnost. Zatim je neophodno izvršiti procenu potrebnog uobičajenog (standardnog) vremena realizacije poslovnih aktivnosti, i potrebnog vremena za realizaciju modifikovanih oblika iste aktivnosti uslovljenih dejstvom faktora trajanja aktivnosti. Na bazi pomenutih podataka, kreira se jednačina vremena. U opštem slučaju, vreme koje se potroši u slučaju tačno određene aktivnosti može se izraziti kao funkcija različitih faktora trajanja aktivnosti. Otuda, vreme potrebno za događaj $K$ aktivnosti $J$ sa $P$ mogućih faktora trajanja aktivnosti može se matematički iskazati opštom jednačinom vremena (Everaert \& Bruggeman, 2007, 17):

$t_{j, k}=\beta_{0}+\beta_{1} \times X_{1}+\beta_{2} \times X_{2}+\beta_{3} \times X_{3}+\ldots \ldots . .+\beta_{p} \times X_{p}$, gde su

\section{$t_{j, k}$ - vreme realizacije događaja $K$ aktivnosti J,}

$\beta_{0}$ - konstantno vreme potrebno za aktivnost J, nezavisno od karakteristika događaja,

$\beta_{1}$ - potrebno vreme za jednu jedinicu faktora trajanja aktivnosti 1 (simbolima $\beta_{0^{\prime}} \beta_{1} \ldots \beta_{p}$ se označavaju konstante $\mathrm{u}$ potrošnji vremena za različite faktore trajanja aktivnosti),
$X_{1}$ - faktor trajanja aktivnosti $1, X_{2}$ - faktor trajanja aktivnosti 2, $X_{p}$ - faktor trajanja aktivnosti $p$,

$p$ - broj faktora trajanja aktivnosti koji određuju vreme potrebno za obavljanje aktivnosti $J$.

Postupak kreiranja jednačina vremena može biti prikazan na hipotetičkom primeru odeljenja prodaje jednog preduzeća (Kaplan \& Anderson, 2007a, 29). Ključne aktivnosti koje se realizuju u odeljenju prodaje ovog preduzeća su: prijem porudžbine, unos porudžbine, otvaranje računa kupca ukoliko se pojavi novi kupac, provera raspoloživosti traženih dobara i utvrđivanje cene u slučaju prijema hitne porudžbine i slanje naloga za isporuku. Polazne pretpostavke analize su:

- da se utvrđuje prosečno vreme potrebno za realizaciju svake od poslovnih aktivnosti odeljenja prodaje i

- da svi zaposleni u prodaji koriste standardni software, pa je vreme potrebno za svaku od aktivnosti moguće jednostavno utvrditi.

Obrada porudžbine zavisi od tri faktora trajanja aktivnosti (uzročnika potrošnje vremena), i to: $X_{1}$ - broj stavki u porudžbini, kao diskretni, $X_{2}$ - tip kupca (novi ili postojeći), kao indikatorski i $X_{3}$ - tip porudžbine (redovna ili hitna), takođe, kao indikatorski faktor. Indikatorski faktori će imati vrednost 1 za novog kupca (i za hitnu porudžbinu), ili vrednost 0 za starog kupca (i redovnu porudžbinu). Analiza vremena realizacije aktivnosti u odeljenju prodaje pokazala je da prijem porudžbine zahteva obradu u trajanju od 2 minuta, a unos svake stavke porudžbine traje 2 minuta. Ukoliko je reč o porudžbini novog kupca, potrebno je otvoriti novi račun, što traje 6 minuta. U slučaju prijema hitne porudžbine neophodno je sprovesti proveru raspoloživosti traženih stavki, što zahteva 7 minuta i utvrditi cenu, što zahteva 3 minuta. Ukupno povećanje vremena obrade porudžbine $u$ slučaju prijema hitne porudžbine iznosi 10 minuta (zbog pojednostavljenja analize aktivnost prijema hitne porudžbine će se razmatrati kao celina, odnosno, koristiće se zbirni iznos potrebnog vremena). Poslednja aktivnost se odnosi na kreiranje i potvrđivanje naloga za isporuku, što zahteva 1 minut (ovo vreme je nezavisno od faktora 
trajanja aktivnosti u slučaju obrade porudžbine, te će biti apstrahovano za svrhe analize).

Nakon identifikovanja prosečnog vremena potrebnog za realizaciju svih poslovnih aktivnosti odeljenja prodaje u slučaju obrade porudžbine, i dodatnog vremena koje se troši usled postojanja uzročnika varijacija $u$ potrošnji vremena, moguće je kreirati jednačinu vremena. U slučaju odeljenja prodaje, vreme prodaje $(t)$ može biti utvrđeno na sledeći način (Todorović, 2013a, 162):

$t=$ prijem porudžbine + unos porudžbine + otvaranje računa za novog kupca + realizacija hitne porudžbine.

Matematički iskazano opštom jednačinom vremena:

$t=\beta_{0}+\beta_{1} \times X_{1}+\beta_{2} \times X_{2}+\beta_{3} \times X_{3}$.

Odnosno, u konkretnom primeru, jednačina vremena za izračunavanje vremena obrade jedne porudžbine $(t)$ ima sledeću formu:

$t=2+2 \times X_{1}+6 \times X_{2}+10 \times X_{3}$.

Ukoliko se pretpostavi da je u preduzeće od novog kupca stigla hitna porudžbina, koja sadrži 10 stavki, jednačina vremena rezultira sledećim vremenom obrade jedne porudžbine:

$t=2+2 \times 10+6 \times 1+10 \times 1=38$ minuta.

Očigledno je da jednačine vremena omogućavaju obuhvatanje i uključivanje kompleksnih poslovnih operacija $u$ obračun troškova na efikasan način. Međutim, ključna pretpostavka uspešnog funkcionisanja računovodstva troškova zasnovanog na primeni TDABC sistema i jednačina vremena jeste adekvatna informaciona podrška u preduzeću. Agresivni prodor informacionih tehnologija na područje računovodstvenog, a posebno upravljačkoračunovodstvenog sistema, rezultira izmenom ne samo njegovih konceptualnih i organizacionih osnova, već, pre svega, unapređenjem i implementacijom novih metodoloških pristupa realizacije računovodstvenih procedura. Važan iskorak $u$ tom pravcu učinjen je dizajniranjem software-a koji ne samo da podržava realizaciju obračuna troškova po aktivnostima, već se i sam kreira na osnovama ovog obračuna. Gotovo da je nezamislivo funkcionisanje savremenih sistema obračuna i upravljanja troškovima bez adekvatne informacione podrške. Software-i ERP tipa pokazuju izuzetne performanse $u$ smislu raspoloživosti i dostupnosti input-a potrebnih za kreiranje jednačina vremena i funkcionisanje TDABC sistema. Otuda je i izračunavanje vremena neophodnog za realizaciju različitih poslovnih aktivnosti jednostavnije $\mathrm{u}$ uslovima primene ERP sistema.

Nakon koncipiranja jednačina vremena i utvrđivanja vremena trajanja poslovnih aktivnosti, može se pristupiti izračunavanju troškova, množenjem vremena potrebnog za realizaciju određene poslovne aktivnost troškovima resursa po jedinici vremena. Budući da se vreme potrebno za realizaciju aktivnosti utvrđuje prema svakom specifičnom slučaju, trošak (T) pojedinačnog događaja $K$, aktivnosti $J$ se utvrđuje prema formuli:

$T=t_{j, k} \times c_{\min }$, gde su:

$c_{\text {min }}$ - troškovi resursa po jedinici vremena (minuti),

$t_{j, k}$ - vreme koje troši događaj $K$ aktivnosti $J$.

Ukupni troškovi nosilaca troškova se utvrđuju sabiranjem svih troškova aktivnosti, odnosno, po formuli:

Ukupni troškovi $=\sum_{i=1}^{n} \sum_{j=1}^{m} \sum_{k=1}^{l} t_{j, k} \times c_{\min ^{\prime}}$ gde su:

$n$ - broj grupa resursa,

$m$ - broj aktivnosti i

$l$ - broj puta ponavljanja aktivnosti.

Preduzeća koja su već kreirala mape svojih poslovnih procesa, u postupku organizaciono-metodološkog koncipiranja TDABC sistema, mogu direktno da pristupe izgradnji jednačina vremena. Ona koja nisu, mogu započeti ovaj proces procenjujući minimalno vreme za realizaciju procesa, ili aktivnosti, odnosno, vreme koje će označiti bazičnim vremenom i koje će biti obeleženo sa $\beta_{0}$. Zatim će saglasno dejstvu određenih faktora trajanja aktivnosti dodavati 
vremena $\beta_{1}$ do $\beta_{p}$ uslovljena varijacijama $\mathrm{u}$ načinu realizacije aktivnosti. Ukoliko se kao primer posmatra odeljenje skladištenja, odnosno, pakovanja proizvoda može se pretpostaviti da pakovanje standardne stavke u paketu zahteva 1 minut, za duži transport potrebno je specifično pakovanje koje zahteva dodatnih 7 minuta, a ukoliko se proizvod transportuje avionom potrebna su dodatna 2 minuta. Umesto pojedinačnog definisanja trajanja svake aktivnosti za svaku moguću kombinaciju karakteristika proizvoda, pristup baziran na vremenu procenjuje tražnju odeljenja za resursima pomoću jednačine vremena, prema kojoj, na bazi učinjenih pretpostavki, vreme pakovanja iznosi $1+7+2$. Za procese sa manjim troškovima i manjim varijabilitetom nije obavezujuće kreiranje jednačina vremena, već je dovoljno korišćenje samo pojedinačnih faktora trajanja aktivnosti (potrošnje vremena). Izgradnja jednačina vremena je obavezujuća za poslovne procese sa velikim troškovima i značajnim varijabilitetom.

U vezi sa koncipiranjem i implementacijom jednačina vremena, mogu se sintetizovati najvažniji zaključci. Potrebno je (Kaplan \& Anderson, 2007a, 35-36):

- fokusirati se na poslovne procese u kojima se najviše vremena troši, i koji imaju najveće troškove;

- precizno definisati sadržinu (obim i opseg) procesa, šta inicira proces i kada;

- pravilno identifikovati ključne faktore trajanja aktivnosti za svaku aktivnost, tj. faktore koji uslovljavaju potrošnju vremena (kapaciteta);

- koristiti lako dostupne faktore trajanja aktivnosti;

- težiti jednostavnosti;

- angažovati zaposlene radnike prilikom izgradnje modela jednačina vremena, ali i njegove ocene.

Pored projektnog tima, zaduženog za koncipiranje modela jednačina vremena, treba potencirati ulogu svih zaposlenih neposredno uključenih $u$ realizaciju aktivnosti i poslovnih procesa. Zaposleni radnici predstavljaju najvažniji izvor informacija $u$ vezi sa obimom i kompleksnošću aktivnosti, odnosno, vremenom potrebnim za njihovu realizaciju. Izrada jednačina vremena zahteva intervjuisanje radnika.
Međutim, predmet intervjua nisu informacije o procentualnoj alokaciji vremena na aktivnosti, kao kod tradicionalnog $\mathrm{ABC}$ sistema, nego o stvarnoj potrošnji vremena. Podaci o potrošenom vremenu po aktivnostima mogu u određenom broju slučajeva da budu procenjeni ili identifikovani direktno, odnosno, dobijeni iz informacionog sistema preduzeća, bez potrebe za intervjuisanjem radnika.

\section{PRIMENA VIŠESTRUKIH FAKTORA TRAJANJA AKTIVNOSTI U JEDNAČINAMA VREMENA}

Jedna od prvih studija u vezi sa praktičnom primenom TDABC sistema i upotrebom jednačina vremena sprovedena je u Belgiji na primeru trgovine na veliko. Jedan od primarnih ciljeva istraživanja bio je analiza sposobnosti TDABC sistema da obuhvati kompleksne poslovne aktivnosti u logistici, te da rezultira tačnim obračunom troškova. Rezultati istraživanja su pokazali da kompleksne poslovne aktivnosti u logistici nije moguće uključiti u model troškova bez upotrebe jednačina vremena sa višestrukim faktorima trajanja aktivnosti (Everaert et al, 2008, 187). Jednačine vremena koncipirane po osnovu većeg broja različitih faktora trajanja aktivnosti mnogo više odgovaraju realnosti, budući da vreme trajanja aktivnosti ne samo da zavisi od brojnih faktora, nego i od njihovog međusobnog odnosa. Autori pomenute studije su razmatrali uticaj primene višestrukih faktora trajanja aktivnosti i njihog međusobnog odnosa na vreme trajanja aktivnosti kroz različite hipotetičke primere (Everaert \& Bruggeman, 2007, 19).

Za svrhe ilustrovanja uticaja međuzavisnosti faktora trajanja aktivnosti na vreme realizacije određene poslovne aktivnosti, biće analizirana dva slučaja. Prvi se odnosi na postojanje dvostruke, a drugi, na postojanje trostruke interakcije između faktora trajanja aktivnosti. Osnovu analize koja sledi će predstavljati već izloženi primer aktivnosti obrade porudžbine $u$ odeljenju prodaje jednog preduzeća, u kome, obrada porudžbine zavisi od tri faktora trajanja aktivnosti, i to: $X_{1}$ - broj stavki u porudžbini, kao diskretni, $X_{2}$ - tip kupca (novi ili postojeći), kao indikatorski, i $X_{3}$ - tip porudžbine (redovna ili hitna), kao indikatorski faktor. 
Indikatorski faktori će imati vrednost 1 za novog kupca (i za hitnu porudžbinu), ili vrednost 0 za starog kupca (i redovnu porudžbinu).

U primeru postojanja dvostruke interakcije između faktora trajanja aktivnosti, uz uvažavanje ranije učinjenih pretpostavki, dodatno se pretpostavlja da u odeljenje prodaje od kupca $X$ pristiže kompleksna porudžbina. Kompleksnost se odnosi na postojanje detaljnih tehničkih podataka u porudžbini, što uslovljava povećanje vremena potrebnog za unošenje stavki ove porudžbine sa 2 na 10 minuta. U ovom slučaju, u jednačinu vremena se mora uključiti novi faktor trajanja aktivnosti. Novi faktor trajanja aktivnosti će biti obeležen sa $X_{4^{\prime}}$ i on određuje vreme obrade po jednoj stavci kompleksne porudžbine. Ovaj faktor ima indikatorski karakter, što znači da će imati vrednost 1 ukoliko je reč o kupcu $X$, ili vrednost 0 ukoliko je reč o bilo kom drugom kupcu. Na bazi učinjenih pretpostavki, može se matematički iskazati opšta jednačina vremena:

$t=\beta_{0}+\beta_{1} \times X_{1}+\left[\beta_{4} \times X_{1} \times X_{4}\right]+\beta_{2} \times X_{2}+\beta_{3} \times X_{3}$

Odnosno, u konkretnom primeru jednačina vremena za izračunavanje vremena obrade jedne porudžbine $(t)$ ima sledeću formu:

$t=2+2 \times X_{1}+\left[8 \times X_{1} \times X_{4}\right]+6 \times X_{2}+10 \times X_{3}$.

Ukoliko bi se pretpostavilo da je u preduzeće od kupca $X$ stigla kompleksna porudžbina, koja sadrži 10 stavki, jednačina vremena bi rezultirala u sledećem vremenu obrade jedne porudžbine:

$t=2+2 \times 10+8 \times 10 \times 1+6 \times 0+10 \times 0=102$ minuta.

U primeru postojanja trostruke interakcije faktora trajanja aktivnosti zadržaće se pretpostavka iz primera broj dva, tj. pretpostavka o pojavi tehnički kompleksne porudžbine. Međutim, biće učinjena dodatna pretpostavka po kojoj ukoliko ovu porudžbinu obrađuje administrativni radnik odeljenja, za obradu je potrebno 8 minuta, a ukoliko je obrađuje lice sa adekvatnim tehničkim znanjima za obradu su potrebna 3 minuta. Iz tih razloga, neophodno je uvesti novi faktor $X_{5}$ koji će označavati tip porudžbine $u$ zavisnosti od lica koje je obrađuje i on je, takođe, indikatorskog karaktera. Ovo znači da će imati vrednost 1 ukoliko porudžbinu obrađuje administrativni radnik, ili vrednost 0 ako je obrađuje tehničko osoblje (pretpostavka je da oba radnika pripadaju istoj grupi resursa). Na osnovu svega, izvodi se opšta jednačina vremena za utvrđivanje vremena obrade jedne porudžbine $(\mathrm{t})$ :

$t=\beta_{0}+\beta_{1} \times X_{1}+\beta_{4} \times X_{1} \times X_{4}+\left[\beta_{5} \times X_{1} \times X_{4} \times X_{5}\right]+\beta_{2} \times X_{2}+$ $+\beta_{3} \times X_{3}$

Odnosno, u konkretnom primeru jednačina vremena za izračunavanje vremena obrade jedne porudžbine $(t)$ ima sledeću formu:

$\mathrm{t}=2+2 \times X_{1}+3 \times X_{1} \times X_{4}+\left[5 \times X_{1} \times X_{4} \times X_{5}\right]+6 \times X_{2}+$

$+10 \times X_{3}$.

Jednačina vremena, pod pretpostavkom da je pristigla porudžbina od kupca $X$, da porudžbina sadrži 3 stavke, i da je obrađuje radnik sa tehnički potrebnim kompetencijama, rezultira sledećim vremenom obrade jedne porudžbine:

$t=2+2 \times 3+3 \times 3 \times 1+5 \times 3 \times 1 \times 0+6 \times 0+10 \times 0=$ 17 minuta.

Primer ukazuje na trostruku interakciju između broja stavki u porudžbini (diskretni faktor), tipa kupca i tipa porudžbine u zasvisnosti od lica koje je obrađuje (oba indikatorski faktori).

Primena višestrukih faktora trajanja aktivnosti, njihovim uključivanjem $u$ jednačine vremena, omogućava preduzećima olakšano prihvatanje sopstvene kompleksnosti bez potrebe za povećanjem složenosti modela obračuna troškova. Umesto definisanja novih aktivnosti i podaktivnosti, uvode se nove jednačine vremena (ili se postojeće proširuju), i čitav postupak se pojednostavljuje. Ovo je druga važna prednost korišćenja jednačina vremena, pored doprinosa povećanju tačnosti obračuna troškova. Da bi obuhvatio povećanu kompleksnost operacija, ili varijacija jedne poslovne aktivnosti, tradicionalni $\mathrm{ABC}$ zahteva dekomponovanje poslovnih operacija na posebne aktivnosti i podaktivnosti, odnosno, izradu 
Registra aktivnosti. Model obračuna troškova koji se nalazi u osnovi TDABC sistema se usložnjava linearno sa povećanjem kompleksnosti poslovanja preduzeća, a ne eksponencijalno, kao model obračuna koji se nalazi u osnovi tradicionalnog $\mathrm{ABC}$ sistema. Otuda, moguće je da implementacija TDABC sistema uslovi zamenu više stotina poslovnih aktivnosti iz Registra aktivnosti sa svega 100 jednačina vremena. Zahvaljujući višestrukim faktorima trajanja aktivnosti, model TDABC sistema se zasniva na manjem broju jednačina vremena od broja aktivnosti koje bi bile neophodne u modelu troškova zasnovanom na tradicionalnom $\mathrm{ABC}$ sistemu, a u isto vreme dozvoljava mnogo veću raznolikost i kompleksnost poslovnih operacija (Kaplan \& Anderson, 2007b, 17).

\section{POTENCIJALNE GREŠKE U JEDNAČINAMA VREMENA}

U procesu kreiranja jednačina vremena mogu nastati dva tip grešaka, i to: identifikacione greške i greške u procenama. Nastanak identifikacionih grešaka je uslovljen zahtevanim visokim nivoom detaljnosti podataka za potrebe kreiranja jednačina vremena, mogućim izostavljanjem određenih faktora trajanja aktivnosti. Posledica njihovog izostavljanja su nedovoljno precizno utvrđena vremena realizacije poslovnih aktivnosti (Hoozee, Vermeire \& Bruggeman, 2012, 442).

Greške $u$ procenama ili greške merenja su brojnije, i nastaju iz više razloga. $S$ tim u vezi, treba imati u vidu da su input-i za formiranje jednačina vremena postojeći ili ex post podaci dobijeni od neposredno angažovanog operativnog osoblja, menadžmenta preduzeća i/ili iz postojećeg informacionog sistema preduzeća. Prvi uzrok grešaka merenja je povezan sa pogrešnim procenama vremena od strane zaposlenih $\mathrm{u}$ vezi sa parametrima jednačina vremena. Pored slučajnih grešaka, pogrešne procene vremena mogu da budu učinjene namerno. Pogrešne procene mogu nastati i kao posledica toga što se od zaposlenih traži procena vremena trajanja aktivnosti $\mathrm{u}$ procentima, umesto u minutama (Cardinaels \& Labro, 2008, 736). Neke psihološke studije pokazuju da su sistematske greške $\mathrm{u}$ procenama vremena, bilo potcenjivanje ili precenjivanje, povezane sa dužinom vremenskog intervala za koji se vreme procenjuje. Rezultati studija su pokazali da se za kraće vremenske intervale, vreme često precenjuje (Fortin \& Rousseau, 1998, 271).

Kao čest razlog pogrešnih procena vremena, $\mathrm{u}$ literaturi se navode netačni ili nepouzdani podaci koji su sadržani u informacionom sistemu preduzeća, iz kojeg se povlače za svrhe kreiranja jednačina vremena i obračuna troškova. Nepreciznost i netačnost input-a rezultira kroz neadekvatno formulisane jednačine vremena $\mathrm{u}$ nekvalitetnim output-ima, tj. netačnom vremenu realizacije poslovnih aktivnosti (poslovnih procesa ili transakcija) (Labro \& Vanhoucke, 2007, 940), te se negativno odražava i na obračunate troškove.

Poslednja grupa uzroka grešaka u procenama vremena povezana je sa organizaciono-metodološkim aspektima implementacije TDABC sistema i posledica je najčešće neadekvatnog nivoa objedinjenosti poslovnih aktivnosti definisanih $\mathrm{u}$ sistemu obračuna troškova ili visokog nivoa povezanosti zadataka u okviru aktivnosti (poslovnih procesa). Ovo je, upravo, jedan od najčešće isticanih potencijalnih nedostataka TDABC sistema. Identifikovanje i izbor poslovnih aktivnosti ima za cilj stvaranje jasne i pouzdane osnove knjigovodstvenog obuhvatanja i obračuna troškova. Reč je o složenom procesu koji je direktno određen veličinom i organizacionom strukturom preduzeća, vrstom delatnosti, ciljevima obračuna troškova i brojnim drugim faktorima. Kreiranje adekvatnih organizaciono-metodoloških rešenja, s tim u vezi, prevazilazi okvire problematike jednačina vremena, odnosno, tangira fundamentalna pitanja organizacije i funkcionisanja TDABC sistema.

Greške u procenama i identifikacione greške nalaze se $\mathrm{u}$ specifičnom međusobnom odnosu. Posledica povećanja nivoa detaljnosti, kroz proširivanje jednačina vremena sa ciljem redukovanja potencijalnih identifikacionih grešaka pri utvrđivanju vremena realizacije određene poslovne aktivnosti, jeste tačniji obračun (tačniji podaci i informacije), ali i veći troškovi kreiranja tih informacija. Budući da su input-i jednačina vremena podložni grešci procene, neizvesno je da li će povećanje nivoa njihove detaljnosti zaista doprineti utvrđivanju tačnijeg vremena realizacije aktivnosti, tj. poslovnih procesa. 
Postojanje potencijalne greške u proceni može usloviti da proširivanje jednačina vremena rezultira većom greškom prilikom utvrđivanja vremena realizacije neke aktivnosti, umesto tačnijim obračunom. Otuda, prilikom dizajniranja jednačina vremena treba težiti uspostavljanju balansa između grešaka u proceni i identifikacionih grešaka.

Imajući u vidu da je posedovanje informacija o veličini potencijalnih grešaka veoma važno za dizajniranje sistema troškova i korisnike njegovih informacija, brojne studije su pokušavale da ovaj problem detaljnije analiziraju. Primenjeni pristupi su bili različiti, i to od simulacionih (Labro \& Vanhoucke, 2007, 941), do statističko-matematičkih. Veoma uspešnim su se pokazali statističko-matematički modeli za određivanje uticaja proširivanja jednačina vremena (dodavanjem parametara, tj. faktora trajanja aktivnosti) na tačnost utvrđenog vremena realizacije aktivnosti. Ovi modeli posmatraju odnos između veličine greške procene i identifikacione greške i njihov uticaj na tačnost utvrđenog vremena realizacije aktivnosti. Analiza na bazi primene statističko-matematičkih modela treba da rezultira minimiziranjem potencijalnih grešaka prilikom dizajniranja i kasnije primene jednačina vremena. Neke od preporuka podrazumevaju proširivanje jednačina vremena faktorima trajanja aktivnosti prema prioritetu (na bazi statističkih pokazatelja: sredine i varijanse), kao i spajanje različitih faktora u jedan, ukoliko između njih postoji značajna korelacija, kako bi se minimizirala identifikaciona greška. Pored toga, pomenuti modeli insistiraju na primeni nekih praktičnih alata i opštih procedura prilikom kreiranja jednačina vremena, kako bi se eliminisale ili minimizirale potencijalne greške.

\section{ZAKLJUČAK}

Zasnovanost na jednačinama vremena i faktorima trajanja aktivnosti (i uzročnicima troškova zasnovanim na trajanju) obezbeđuje TDABC sistemu značajne metodološke prednosti $\mathrm{u}$ odnosu na ranija rešenja obračuna troškova po aktivnostima, i visoke izveštajne performanse. Najvažnije su sledeće:
- TDABC sistem obezbeđuje veću tačnost obračuna troškova, odnosno, utvrđene cene koštanja. Preciznost TDABC sistema zasnovana je na adekvatnoj alokaciji troškova na nosioce troškova u skladu sa stvarnom potrošnjom resursa. Povećanje tačnosti i fleksibilnosti obračuna troškova ne povećava kompleksnost obračuna, usled mogućnosti koncipiranja jednačina vremena sa višestrukim faktorima trajanja aktivnosti;

- primena tradicionalnog $\mathrm{ABC}$ sistema zahteva da se za svrhe ažuriranja sistema gotovo na kraju svakog obračunskog perioda sprovodi intervjuisanje zaposlenih radnika radi ponovne procene vremena potrebnog za realizaciju poslovnih aktivnosti. Potreba za ponovnim procenama potrebnog vremena može biti uslovljena i uvođenjem novih proizvoda, novih poslovnih procesa, pojavom novih kupaca i sl. U uslovima primene TDABC sistema, jednačine vremena se konstantno menjaju sa povećanjem broja i složenosti aktivnosti, u uslovima uvođenja novih proizvoda, procesa, kupaca ili kanala distribucije, omogućavajući na taj način efikasnije ažuriranje sistema troškova. Takođe, izostavljanje neke važne varijacije procesa, potprocesa ili aktivnosti se $u$ uslovima primene jednačina vremena jednostavno prevazilazi njihovim proširivanjem;

- jednačine vremena imaju posebnu upotrebnu vrednost iz perspektive menadžmenta preduzeća. Budući da obuhvataju bazične faktore koji uzrokuju tražnju za kapacitetom procesa, uključujući i promene u efikasnosti procesa, obimu i miksu proizvodnje i dr, jednačine vremena su pogodne za simulaciju budućnosti, za sprovođenje šta-ako analize, unapređenje procesa budžetiranja i efikasnu analizu kapaciteta preduzeća;

- postupak koncipiranja jednačina vremena često rezultira identifikovanjem procesa, aktivnosti ili pojedinih faza aktivnosti koje su neefikasne i izazivaju nepotrebno trošenje, tj. rasipanje resursa. Time obezbeđuju svojevrstan impuls za pokretanje inicijativa unapređenja poslovnih procesa, odnosno, jednačine vremena pružaju osnovu za kontinuirana operativna unapređenja 
poslovnih procesa (Everaert et al, 2012, 41; Hoozee \& Bruggeman, 2010, 185);

- u postupku kreiranja jednačina vremena može doći do pojave identifikacionih ili grešaka procene. Brojne empirijske studije su se bavile analizom i načinima za eliminisanje ovih potencijalnih grešaka (Hoozee et al, 2012; Cardinaels \& Labro, 2008; Fortin \& Rousseau, 1998; Labro \& Vanhoucke, 2007). Zaključci upućuju na primenu određenih praktičnih alata i tehnika (simulacionih i statističko-matematičkih) i opštih procedura prilikom kreiranja jednačina vremena kako bi se eliminisale ili minimizirale greške.

Sintetizovano, ključni atributi metodologije, odnosno, modela obračuna troškova zasnovanog na jednačinama vremena su: jednostavnost i fleksibilnost, pogodnost za prilagođavanje i proširivanje, preciznost i tačnost, pojednostavljeno održavanje i ažuriranje. Odnosno, zahvaljujući jednačinama vremena, TDABC obezbeđuje efektivniji i efikasniji obračun troškova i utvrđivanje cene koštanja. Izazovi vremena i promena daće odgovor na pitanje dugoročne održivosti i primenljivosti ovog savremenog sistema obračuna i upravljanja troškovima. Ipak, učinjena analiza i izvedeni zaključci potvrđuju postavljenu hipotezu na početku rada.

Učinjena analiza i izneti zaključci daju doprinos razumevanju suštine, metodologije i izveštajnih performansi TDABC sistema, te imaju značajnu upotrebnu vrednost iz perspektive primene i disperzije ovog sistema u praksi preduzeća Republike Srbije. Izloženi primeri $u$ vezi sa koncipiranjem jednačina vremena pružaju osnovu za unapređenje TDABC sistema $u$ preduzećima koja ga već primenjuju i omogućavaju prevazilaženje problema i pretpostavki organizaciono-metodoloških priprema za implementaciju i funkcionisanje ovog sistema kod potencijalnih korisnika.

Ukupni istraživački napori u ovom radu, dominantno usmereni ka organizaciono-metodološkim aspektima TDABC sistema, otvorili su brojna pitanja i dileme. Analiza ovih pitanja će zaokupiti pažnju istraživača $\mathrm{u}$ budućnosti, pre svega, u vezi sa izgradnjom računovodstvenog modela zasnovanog na TDABC sistemu u praksi preduzeća. Šire teorijsko-metodološko utemeljenje i difuzija TDABC sistema u praksi će omogućiti realizaciju drugih, statističko-matematičkih metodologija istraživanja. Kao korisna osnova budućih istraživanja može poslužiti analiza brojnih studija iz svetske prakse u vezi sa primenom TDABC sistema.

\section{REFERENCE}

Antić, Lj. (2012). Koncepti obračuna i upravljanja troškovima u poslovnom okruženju. U R. Stojanović (Ur.), Ekonomskofinansijska kriza i računovodstveni sistem (str. 144-165). Beograd: SRRS.

Antić, Lj. i Georgijevski, M. (2010). Obračun troškova po aktivnostima zasnovan na vremenu. Ekonomske teme, 48(4), 499-513.

Buchheit, S. (2003). Reporting the Cost of Capacity. Accounting Organizations and Society, 28(6), 549-565. doi: 10.1016/S03613682(02)00014-4.

Cardinaels, E., \& Labro, E. (2008). On the determinants of measurement error in time-driven costing. The Accounting Review, 83(3), 735-756.

Everaert, P., \& Bruggeman, W. (2007). Time-Driven ActivityBased Costing: Exploring the Underlying model. Cost Management, 21(2), 16-20.

Everaert, P., Bruggeman, W., \& De Creus, G. (2008). Sanac Inc.: from $\mathrm{ABC}$ to Time driven $\mathrm{ABC}$ (TDABC) - an instructional case. Journal of Accounting Education, 26(3), 118-154. doi: 10.1016/j.jaccedu.2008.03.001.

Everaert, P., Bruggeman, W., Sarens, G., Anderson, S., \& Levant, Y. (2008). Cost modeling in logistics using timedriven ABC: Experiences from a wholesaler. International Journal of Physical Distribution \& Logistics Management, 38(3), 172-191. doi: 10.1108/09600030810866977.

Everaert, P., Cleuren, G., \& Hoozee, S. (2012). Using TimeDriven $A B C$ to identify operational improvements: a case study in a university restaurant. Cost Management, 26(2), 4148 .

Fortin, C., \& Rousseau, R. (1998). Interference from short-term memory processing on encoding and reproducing brief durations. Psychological Research, 61(4), 269-276. doi: 10.1007/ s004260050031.

Gilbert, S. (2007). Adding Time to ABC. Working Knowledge, Harvard Business School, Retrieved 25.06.2014. from http:// www.exed.hbs.edu/assets/documents/activity-basedcosting.pdf. 
Hoozee, S., \& Bruggeman, W. (2010). Identifying operational improvements during the design process of time-driven $\mathrm{ABC}$ system: the role of collective worker participation and leadership style. Management Accounting Research, 21(3), 185198. doi: 10.1016/j.mar.2010.01.003.

Hoozee, S. M., Vermeire, L., \& Bruggeman, W. (2012). The impact of refinement on the accuracy of time-driven ABC. Abacus, 48(4), 439-472. doi: 10.1111/j.1467-6281.2012.00366.x.

Janjić, V. i Todorović, M. (2012). Izveštajni dometi obračuna troškova po aktivnostima u poslovnom odlučivanju. Teme, $36(1), 237-252$.

Kaplan, R., \& Anderson, S. (2007a). Time - Driven Activity Based Costing: A Simpler and more Powerful path to higher profits. Boston, USA: Harvard Business School Publishing Corporation.

Kaplan, R., \& Anderson, S. (2007b). The innovation of Time Driven Activity-Based Costing. Cost Management, 21(2), 5-15.

Labro, E., \& Vanhoucke, M. (2007). A simulation analysis of interactions among errors in costing systems. The Accounting Review, 82(4), 939-962.
Malinić, S. i Todorović, M. (2011). Konceptualne osnove obračuna i upravljanja troškovima po aktivnostima baziranom na vremenu. Ekonomika preduzeća, 59(3-4), 206213.

Szuhta, A. (2010). Time-Driven Activity-Based Costing in Service Industries. Social Science, 67(1), 49-60.

Todorović, M. (2008). Koncipiranje analitičkog kontnog plana računovodstva troškova u skladu sa MRS/MSFI i Zakonom o računovodstvu i reviziji. Ekonomski horizonti, 10(1-2), 131158.

Todorović, M. (2013a). Obračun troškova po aktionostima baziran na vremenu -instrument integrisanog upravljanja lean poslovnim procesima. Neobjavljena doktorska disertacija, Ekonomski fakultet Univerziteta u Kragujevcu, Kragujevac, Srbija.

Todorović, M. (2013b). Izbor uzročnika troškova u funkciji izgradnje optimalnog sistema obračuna troškova po aktivnostima. Računovodstvo, 57(7-8), 61-71.

Tse, M., \& Gong, M. (2009). Recognition of Idle Resources in TDABC and RCA. Jamar, 7(2), 41-54.

Primljeno 14. novembra 2014, nakon revizije, prihvaćeno za publikovanje 15. decembra 2014. Elektronska verzija objavljena 22. decembra 2014.

Mirjana Todorović je docent na Ekonomskom fakultetu Univerziteta u Kragujevcu, gde je doktorirala u užoj naučnoj oblasti Računovodstvo, revizija i poslovne finansije. Ključne oblasti njenog interesovanja su savremeni sistemi obračuna i upravljanja troškovima, i različiti aspekti računovodstvenog informacionog sistema preduzeća. 


\title{
THE KEY ASPECTS OF THE BUILDING AND APPLICATION OF TIME EQUATIONS IN COST CALCULATION
}

\author{
Mirjana Todorovic \\ Faculty of Economics, University of Kragujevac, Kragujevac, Serbia
}

\begin{abstract}
In addition to the capacity cost rate, the key parameter of Time-Driven Activity Based Costing - the TDABC is the time required for the realization of each business activity. In accordance with the TDABC methodology, the above-mentioned time is calculated by using time equations. Therefore, the total time required for the realization of a certain business activity is obtained by adding a normal (standard) time to the additional time required for performing modified forms of one and the same activity. The aim of this paper is to analyze the role and importance as well as various aspects of the building of time equations from the perspective of the organizational and methodological preparation for the realization and functioning of the TDABC. The research results show that the application of time equations leads to the increased accuracy of the calculation of costs and a product cost, reduces the complexity of the organizational and methodological preparation for the implementation and functioning of the TDABC system, i.e. enables the realization of a more effective and efficient costs calculation
\end{abstract}

Keywords: calculation of costs, Time-Driven Activity Based Costing, capacity cost rate, time equations, time drivers

JEL Classification: M41, M49 